\title{
The Rising Double Heterozygous Cases of Haemoglobinopathies In Paediatric Population-A Hospital Based Cross Sectional Study
}

\author{
Vikas Dagar, ${ }^{1}$ Rajesh Kate ${ }^{2}$,Ashwinkumar Barsagade ${ }^{1}$,Pradeep Male ${ }^{3}$ \\ ${ }^{I}$ (Assistant Professor Pathology Department, Maharashtra Universityof Health Science,Nashik, India) \\ ${ }^{2}$ (Associate Professor Pathology Department, Maharashtra University of Health Science,Nashik, India) \\ ${ }^{3}$ (Junior resident Pathology Department, Maharashtra University of Health Science,Nashik, India)
}

\begin{abstract}
In this study various abnormal haemoglobin fractions on HPLC were observed in 158 cases out of the total 300 screened paediatric anaemic cases. Of the 300 paediatric cases, samples analyzed on CE-HPLC for haemoglobinopathies, maximum 67 (22.33\%) cases were diagnosed as $S-\beta$ double heterozygous, 39(13\%) as sickle cell trait, 27 (9\%) as $\beta$-thalassaemia major, 10 (3.33\%) as sickle cell disease, 05 (1.66 \%) were diagnosed as $\beta$-thalassaemia trait, 03 ( $1 \%$ ) were unknown haemoglobins, $02(0.66 \%)$ as $\mathrm{Hb}$ E- $\beta$-thalassaemia double heterozygous, $02(0.66 \%)$ as $S C T+H b D$ trait and $01(0.3 \%)$ as $\mathrm{Hb}$ E trait.
\end{abstract}

Keywords:-Double heterozygous, paediatric haemoglobinopathies

\section{Introduction}

The sickling disorders- HbSS, HbSD, HbSE, HbS $\beta$ - thalassemia and other compound heterozygous hemoglobinopathies are all clinically significant, as these combinations present with different manifestations and degrees of severity, making precise identification important. ${ }^{1}$ Majority of patients homozygous for $\beta$ thalassaemia or SCD; or double heterozygotes of $\beta$-thalassaemia with $\mathrm{HbS}$ or $\mathrm{HbE}$ have severe disease starting from infancy and require regular blood transfusion for survival and succumb eventually to myriad range of causes by adolescence or adulthood. Optimum management with adequate iron chelation or early hospitalization and treatment of infections, crisis as in a case of SCD is not available to vast majority ${ }^{2,3}$.Automated cationexchange High Performance Liquid Chromatography (HPLC) has emerged as an excellent screening tool for diagnosing these abnormal hemoglobins/ thalassemic states. ${ }^{4,5}$ The simplicity of the automated system with internal sample preparation, superior resolution, rapid assay time, and accurate quantification of hemoglobin fractions makes this an ideal methodology for the routine clinical laboratory. ${ }^{5}$

The sparse literature available regarding haemoglobinopathies in children necessitated the need for the present study and early screening and detection of haemoglobinopaties will in turn help in early and better management of afflicted child, family counselling, planning for next child by parents. Understanding the actual rate or prevelance should facilitate the planning of public policies and other actions that can contribute towards the reducing homozygote's from the population and improving the quality of life of people with haemoglobinopathies.

\section{Material And Method}

This study cleared by institutional ethic commette of Government medical college NANDED Maharashtra, india. This is a hospital based cross sectional study in which a total of 300 anaemic paediatric patients (6months to 14 years of age) along with there parents blood samples were analysed for $\mathrm{Hb}$ variants who were referred from pediatric department of GMC nanded maharashtra,from various Primary health centre and rural health centre around nanded region of maharashtra. The study was conducted for 18 month from January 2013 to June 2014.patients were having clinical manifestation like anemia, hepatospleenomegaly, weakness, repeated infection, aches and pain, fever etc. Detail clinical history including ethnic origin, age sex, blood transfusion etc along with family history was taken.After consent from parents, $2 \mathrm{ml}$ of venous blood collected in EDTA (Ethylene diamine tetra-acetic acid) coated vaccutainers from each patient and there parents wherever required. Patients transfused in last 3 months and age less then 6 month were not included in study. The Hematological profile of cases was done, which included PS, CBC including RBC Indices, reticulocyte count etc. The complete blood count was done by using orphee-mythic cell counter. With the help of Bio rad thalassemia short programme HPLC exact percentage of $\mathrm{HbS}, \mathrm{HbF}, \mathrm{HbA}_{2}$ and $\mathrm{HbA}_{0}$ was estimated to classify the cases.Then study of family members accompanying the cases was done to confirm the diagnosis and to determine ethnic background. The statistical analysis of all data was carried out using Microsoft Office Excel and SPS 16. 


\section{Results}

During the study period of one year, a total of 300 paediatric cases were studied. The patient population age ranges from 6 months to 14 years. Out of 300 screened patients 158 cases were having abnormal haemoglobin. Out of abnormal $\mathrm{Hb}$ we found 71 cases of double heterozygous haemoglobinopathies that is very high.

The most common $\mathrm{Hb}$ abnormalirty detected was $\mathrm{S} \beta$ thalasaemia cases in 67 patients. The distribution of different pattern of $\mathrm{Hb}$ variant in study population has been shown in TABLE NO 1, Interpretation of results of HPLC was done on the basis of retention time, percentage of Haemoglobin, and peak characteristics. E $\beta$ thalassaemia cases were 2 in number and SCT $+\mathrm{HbD}$ cases were also 2 in number.

Out of 71 double heterozygous haemoglobinopathis, there were 32 males and 39 female. Age wise distribution is shown in TABLE no 2, In which maximum 28nuber cases were under age group of 6-10 years, followed by 11-14 year in which cases were 24 and the minimum number cases were among 6month to 5years of age that is 18 cases.

Out of 71 cases of double heterozygous hemoglobinopathies cansanguinous marriage history was given positive in 26 cases. Caste wise distribution of double heterozygous cases shows maximum cases from boudha and banjara community i.e 35 and 16 cases. Table no 3 shows various caste and number of double heterozygous cases

Haematological profile in double heterozygous cases shown by table no 4 . The average haemoglobin among 67 cases of $\mathrm{S}$ - beta thalassaemia cases was around 8.17 $\pm 2.16 \mathrm{~g} / \mathrm{dl}$. The mean MCV level were found to be around 75.74 $\pm 9.6 \mathrm{fl}$.The mean MCHC level was around $23.65 \pm 4.00 \mathrm{~g} / \mathrm{dl}$

\section{Table And Figure}

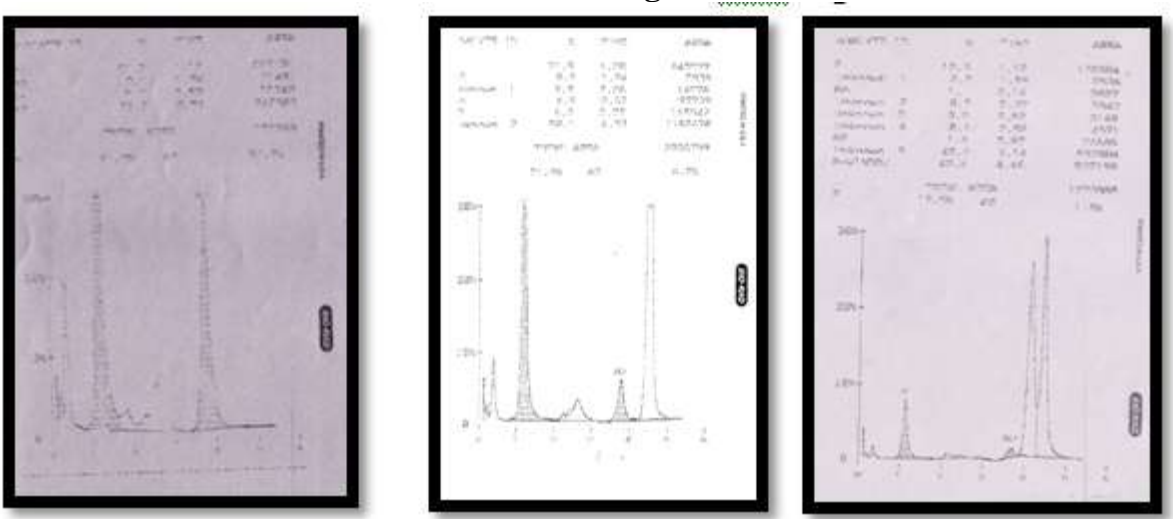

Fig 1 :-HPLC graph of showing double heterozygous haemoglobinopathies cases .Graph (a) showing HbE-Beta thalassaemia cases, graph (b) HbS-beta talassaemia case and Graph (c) showing HbS trait + HbD trait

\begin{tabular}{|l|l|l|l|}
\hline Sr.no. & Haemoglobin Pattern & No. of Cases & Percentage \% \\
\hline 1. & Normal & 142 & $47.33 \%$ \\
\hline 2. & Sickle cell trait & 39 & $13 \%$ \\
\hline 3. & Sickle cell disease & 10 & $3.33 \%$ \\
\hline 4. & $\beta$ thalassaemia major & 27 & $9 \%$ \\
\hline 5. & $\beta$ thalassaemiaintermedia & 01 & $0.33 \%$ \\
\hline 6. & $\beta$ thalassaemia trait & 05 & $1.66 \%$ \\
\hline 7. & S $\beta$-thalassaemia & 67 & $22.33 \%$ \\
\hline 8. & E $\beta$-thalassaemia & 02 & $0.66 \%$ \\
\hline 9. & Heterozygous HbE & 01 & $0.33 \%$ \\
\hline 10. & SCT + HbD trait & 02 & $0.66 \%$ \\
\hline 11. & Alpha thalassaemia & 01 & $0.33 \%$ \\
\hline 12. & Unknown & 03 & $1 \%$ \\
\hline & Total & $\mathbf{3 0 0}$ & $\mathbf{1 0 0 \%}$ \\
\hline
\end{tabular}

Table 1- Haemoglobin patterns found during screening all cases.

\begin{tabular}{|l|l|}
\hline AGE & Cases \\
\hline $0-5$ yrs & 18 \\
\hline $6-10$ yr & 28 \\
\hline $11-14 y r$ & 25 \\
\hline
\end{tabular}

Table no 2:-Age sex distribution of double heterozygous cases double heterozygous cases. 


\begin{tabular}{|l|l|}
\hline CASTE & NO OF CASES \\
\hline Boudha & 35 \\
\hline Banjara & 16 \\
\hline Muslim & 5 \\
\hline Andh & 2 \\
\hline Gond & 2 \\
\hline Gowari & 2 \\
\hline Kumbhar & 2 \\
\hline Mahar & 2 \\
\hline Sikh & 2 \\
\hline Dhangar & 1 \\
\hline Mang & 1 \\
\hline Wadhar & 1 \\
\hline
\end{tabular}

Table no 3:-Caste wise distribution of various cases of double heterozygous haemoglobinopathies.

\begin{tabular}{|l|l|}
\hline $\begin{array}{l}\text { Variable } \\
(\mathbf{N})\end{array}$ & $\begin{array}{l}\text { SB thal } \\
(\mathbf{6 7})\end{array}$ \\
\hline Hb(g/dl) & $8.17 \pm 2.16$ \\
\hline RBC(10/ul) & $3.9 \pm 0.90$ \\
\hline PCV(\%) & $25.74 \pm 6.34$ \\
\hline MCV(fl) & $75.74 \pm 9.6$ \\
\hline MCH(pg) & $23.65 \pm 4.00$ \\
\hline MCHC(g/dl) & $28.65 \pm 4.12$ \\
\hline HBA0(\%) & $24.90 \pm 10.67$ \\
\hline HBA2(\%) & $6.11 \pm 2.27$ \\
\hline HBF(\%) & $17.54 \pm 10.58$ \\
\hline HBS(\%) & $52.74 \pm 16.94$ \\
\hline
\end{tabular}

Table no 4:-Haematological profile in double heterozygous cases.

\begin{tabular}{|l|l|l|l|l|l|l|}
\hline No & Study & & HbF & HbA0 & HbA2 & HbS \\
\hline 1. & $\begin{array}{l}\text { S.S.Ambekar } \\
\text { 2001(IJHG) } \\
n=4\end{array}$ & $\mathrm{~S}^{0}$ & $25 \%$ & $5 \%$ & $5 \%$ & $68 \%$ \\
\cline { 3 - 6 } & $\mathrm{S} \beta^{+}$ & $28 \%$ & $19.8 \%$ & $3.5 \%$ & $61.7 \%$ \\
\hline 1. & $\begin{array}{l}\text { Rao Seema et al }{ }^{46} 2010 \\
\mathrm{n}=6\end{array}$ & $18.3 \pm 8.4$ & $4.6 \pm 1.8$ & $4.5 \pm 0.6$ & $71.7 \pm 5.8$ \\
\hline 2. & $\begin{array}{l}\text { Dangi et al }{ }^{45} 2010 \\
\text { n=16 }\end{array}$ & $15.52 \%$ & $13.1 \%$ & $4.19 \%$ & $57.17 \%$ \\
\hline 3. & $\begin{array}{l}\text { C.Vani et al }{ }^{48} 2011 \text { th-60 } \\
n=14\end{array}$ & $19.2 \%$ & - & - & $65.6 \%$ \\
\hline 5. & $\begin{array}{l}\text { Present Study } \\
\text { n=67 }\end{array}$ & $17.54 \pm 10.58$ & $24.90 \pm 20.67$ & $6.11 \pm 2.27$ & $52.74 \pm 16.94$ \\
\hline
\end{tabular}

Table no 5:-Showing comparision of haemoglobin $\mathrm{HbS}, \mathrm{HbA} 0, \mathrm{HbA} 2$ and $\mathrm{HbF}$ level in diagnosed cases of SBeta thalassaemia cases in various study with present study.

\section{Discussion}

4.1 Average age of presentation in present study was found to be 13.4 years which is comparable to the study conducted by Balgir et $\mathrm{al}^{6}$ (13.5 years) in 2010 and Tyagi et $\mathrm{al}^{7}$ (14.2 years) in 2003.

4.2Incidence of double heterozygous cases in present study is $46.8 \%$ which is comparable to the study conducted by Dangi et $\mathrm{al}^{8}(45.7 \%)$ in 2010 and Tyagi et $\mathrm{al}^{7}(34.04 \%)$ in 2003. R.S Balgir et al ${ }^{6}$ in(2010) reported the incidence rate of $32.11 \%$ of double heterozygous cases amongst the sickle disorder patients. This difference is may be due to regional variation. The probable cause for high detection of Sickle -Beta Thalassemia cases as compared to the other studies is that, family HPLC screening was done meticulously in the present study.

4.3 In the present study history of consanguineous marriage was the predominant cause for the occurrence of double heterozygous cases. It was found in 65 cases (55.55\%). Patel D.K et $\mathrm{al}^{9}$ and Tariq H.A et $\mathrm{al}^{10}$ also stated that the main reason for increased incidence of double heterozygous cases in particular communities like SC and Muslims is consanguinity which is comparable to the findings of present study.

4.4 The caste wise distribution was carried out in Nanded and the nearby zone. It was found that the maximum number of double heterozygous cases were found in Boudha community i.e 29 cases $(24.78 \%)$ 
The Rising Double Heterozygous Cases Of Haemoglobinopathies In Paediatric Population....

followed by Muslims 25 cases (21.37\%). Banjara contributed to 12 cases (10.25\%), Matang 12 cases (10.25\%), Chambar 10 cases $(8.55 \%)$, Teli9 cases (7.70\%), kunbi 7 cases (5.99\%) and others $13(11.11 \%)$.

4.5 Table 5 shows comparision of various study and the present study in which the HbS levels were $>50 \%$.

In all the studies the average $\mathrm{HbF}$ levels were high $>15 \%$, in present study it was (17.54 \pm 10.58$)$

The average $\mathrm{HbA} 2$ level in present study was $(6.11 \pm 2.27)$.

In 67 cases out of 67 cases,family HPLC study supported the diagnosis of double heterozygous S $\beta$ Thalassemia.

\section{Conclusion}

Haemoglobinopathies form a significant proportion of hereditary disorders in paediatric population leading to a range of myriad complication, leading to mortality in large number of afflicted patients. Most common forms of these includes thalassaemia and sickle cell anaemia. Published literature includes various reports on screening patient using HPLC in adults as well as paediatric population .However, there is paucity of literature on studies on exclusive paediatric population. So we have performed this study with an aim to report the occurrence of double heterozygous cases in paediatric population attending tertiary hospital in our region.

\section{Reference}

[1]. A. Rangan, A.Handoo,S.Sinha,R.Saxena,I.C.Verma,s.Kumar et al. Utility of family studies in diagnosing abnormal hemoglobins/ thalassemic states. Indian Journal of Pediatrics, Volume 76-June, 2009;76(6); p 615-21

[2]. Ana Caroline NovaesSoaresa, Isabella ChagasSamicoa, Aderson Silva Araújob, Marcos André C. Bezerrac, BetâniaLucenaDominguesHatzlhoferb. Follow-up of children with hemoglobinopathies diagnosed by the Brazilian Neonatal Screening Program in the State of Pernambuco. Rev bras hematolhemoter. 2014;36(4):250-55

[3]. Kabramadhulika, Menon P. S. N.The challenge of haemoglobinopathies in India. The national medical Journal of India, 1999;12(5):198-201

[4]. Rangan A, Handoo A, Sinha, Saxena S, Verma I.C, Kumar S et al. Utility of family studies in diagnosing abnormal hemoglobins/ thalassemic states. Indian Journal of Paediatrics. 2009 june; 76(6): 615-21

[5]. AllaJoutovsky, Joan Hadzi-Nesic,MichaelA.Nardi. HPLC Retention Time as a Diagnostic Tool for Hemoglobin Variants and Hemoglobinopathies: A study of 600000 samples in a Clinical Diagnostic Laboratory. Clinical chemistry. 2004 50(10); 1736-47.

[6]. ) Balgir TS. Phenotypic diversity of sickle cell disorders with special emphasis on public health genetics in India. Currsci 2010;98:1906-1102

[7]. Tyagi S, Choudhary VP, SaxenaR.Subclassification of HbS syndrome, is it necessary? Clin Lab Haem 2003;25:377-81

[8]. Dangi CBS, Sajid M, Saawke GK, Ambhore J. Sickle Cell Hemoglobinopathies in district Bhopal. Indian J Hum Genet 2010 MayAug; 16(2):100-02

[9]. Patel DK. Epidemiology \& clinical aspects of sickle cell disease in India (online) Available from URL: http://www.cehmob.org.br/simposio/imagens/download/palestras/PATEL D Kumar.pdf

[10]. Tariq HA.Sickle cell trait; prevalence among primary school children in Makkah city. The professional 2004;11:197-202 